\title{
The Right of Minorities to Political PARTICIPATION UNDER THE ETHIOPIAN ELECTORAL SYSTEM
}

Beza Dessalegn*

\begin{abstract}
Broad representation of different ethnic groups has implications in stability and the quality of democracy. The right to political participation is largely realized through the electoral system of a country. The choice among electoral systems should thus take various factors into account including the need for securing equitable representation, including minority groups. It is argued that the 'first past the post' system embodied in Ethiopia's electoral law denies national and regional minorities equitable and adequate share of political power in the respective federal and regional councils. Hence, taking into consideration Ethiopia's long history of competing ethnic nationalisms and lack of consensus, there is the need for securing adequate representation proportional to the numerical presence of minorities in constituencies in lieu of stubborn adherence solely to the majoritarian plurality system.
\end{abstract}

\section{Key words}

Political participation, minorities, electoral law, electoral systems, ethnic groups, equitable representation, Ethiopia

DOI http://dx.doi.org/10.4314/mlr.v7i1.4

\section{Introduction}

Electoral system design is a key mechanism in the broader institutional design approach to the resolution of conflict in multiethnic societies. ${ }^{1}$ This requires the development of electoral systems so that democracies can function properly. ${ }^{2}$ Elections, not only enable citizens to elect political leadership, but also provide

* Lecturer at Hawassa University, College of Law and Governance, School of Law.

${ }^{1}$ Stefan Wolf, Electoral Systems Design and Power Sharing Schemes in Ian O'Flynn and David Russell (eds.), 2005, Power Sharing: New Challenges for Divided Societies, (Chase Publishing Services Ltd.), p. 59.

2 Jack Bielasiak (2002), "The Institutionalization of Electoral Party Systems in Post Communist States", Comparative Politics, Vol. 34, No. 2, (Jan 2002), p. 189. 
the mechanism through which people can exercise control over their government officials. $^{3}$

The electoral system adopted by a country depends more on its political culture rather than any abstract consideration into the relative merits of different voting methods. ${ }^{4}$ For example, countries with British political heritage are more inclined to plurality and majority systems, while those influenced by continental Europe have been more inclined towards proportional systems. ${ }^{5}$ It is also determined by how a country's political life is organized, taking into account issues such as ethnicity, religion or a secular identity.

The right to political participation, which is a fundamental human right, especially, as applied to citizens of a country, should be implemented by the electoral system of a country to assure the equitable representation of minority groups. This article deals with the right to political participation of minorities in Ethiopia from the vantage point of the electoral system adopted. I argue that, the voting methods espoused as well as the electoral law's language requirement for political empowerment of ethnic groups have not provided a favourable atmosphere for minorities found both at the federal and regional levels with respect to their right to political participation.

The first section of the article highlights the types of electoral systems that exist in the world today. Section 2 briefly discusses how ethnicity as a mode of political organization gained momentum and reached its political maturity in Ethiopia. The article further discusses the nexus between electoral systems and minority rights in the third section. This is further supported by Section 4 in which an attempt is made to show how ethnic group determination and minority right assertion took root in the Ethiopian federal system. Although general reference is made to the federal and regional levels, the article discusses regional minorities in the context of regional states. Section 5 addresses the right to political participation in the context of Ethiopia's electoral system. The implication of the demand by several ethnic groups of their right to political participation is discussed under section 6 , followed by the last section which deals with the way forward with regard to some of the issues.

${ }^{3}$ Benjamin Reilly (2006), Democracy and Diversity: Political Engineering in The AsiaPacific, Oxford University Press, pp. 97-100.

${ }^{4}$ Arend Lijphart (2008), Thinking About Democracy: Power Sharing and Majority Rule in Theory and Practice, (Routledge, Taylor and Francis Group), p. 160.

${ }^{5}$ Ibid. 


\section{Electoral Systems: A Brief Overview}

Electoral systems may vary along three generic dimensions: "the ballot structure, the district structure and the electoral formula". ${ }^{6}$ The ballot structure determines how citizens cast their votes and how their votes are counted. This structure mainly focuses on five distinct features. The entities for which citizens may vote, the number of votes that they cast for these entities, the category of votes cast, the ballot system and to the extent to which relevant vote totals are affected by the votes cast. ${ }^{7}$

The district structure refers to the numbers, hierarchy, and magnitude of the electoral districts used in the system. An electoral district is defined as "a geographical area within which votes are aggregated and seats allocated." There may be one single national electoral district or many. With multiple districts, this structure may be allocated to a single tier or organized hierarchically into multiple lower and upper tiers. ${ }^{8}$ Finally, there is the electoral formula which determines how votes are translated into seats. The most basic and well known formulas are the majority, proportional representation and mixed systems. ${ }^{9}$

As Moster observes, "[t]he existence of significant ethnic cleavages have long held states in an insurmountable difficulty of maintaining democracy and the task has been even harder in emerging democracies". ${ }^{10}$ For this purpose, different states have sought different mechanisms on how to overcome these obstacles and successfully implant democracy in the face of deep ethnic cleavages. $^{11}$

To this end, achieving broad representation of different ethnic groups has important implications for the stability and quality of democracy. Legislative representation carries powerful symbolic power for ethnic minorities and often becomes an end in itself even when minorities have little or no chance of participating in the governing coalition. ${ }^{12}$

Electoral systems dictate how votes are counted into seats and they have a number of pragmatic applications which were very much contentious in many countries during the 1990 's, and this has given prominence to the issue thereby

\footnotetext{
${ }^{6}$ Jan Teorell and Catharina Lindstedt (2010), "Measuring Electoral Systems”, Political Research Quarterly, Vol. 63, No. 2, (June 2010), p. 435.

${ }^{7}$ Ibid.

${ }^{8}$ Ibid.

${ }^{9}$ Ibid.

${ }^{10}$ Robert G Moster (2008), "Electoral Systems and the Representation of Ethnic Minorities: Evidence from Russia”, Comparative Politics, Vol. 40, No. 3, (April 2008), p. 273.

${ }^{11}$ Ibid.

${ }^{12}$ Ibid.
} 
elevating it from the margin to the mainstream in the political agenda. ${ }^{13}$ The following section briefly outlines the main variations in electoral systems.

\subsection{Classification of Electoral Systems}

The majoritarian system includes plurality, second ballot, and alternative voting. The proportional and semi-proportional systems inculcate the single transferable vote, the limited vote including open and closed party lists using largest remainders and highest average formula. The third type is the mixed system, such as the additional members system thereby combining majoritarian and proportional elements. ${ }^{14}$

\subsubsection{Majoritarian electoral systems}

This is by far the oldest electoral system, dating back at least to the twelfth century, and also is the simplest. ${ }^{15}$ This category can be subdivided into those requiring candidates to win a simple majority, or an absolute majority (50+ percent) of votes to be elected. ${ }^{16}$

\section{a) Plurality system}

In the plurality system, otherwise known as "first-past-the post" or "winner takes all", candidates usually do not need to pass a minimum threshold of votes. Nor do they require an absolute majority to be elected. Instead, all they need is a simple plurality, that is, one more vote than their closest rival. ${ }^{17}$ Hence, for example, in seats where the vote splits almost equally among three candidates, the winning candidate may have only 35 percent of the vote, while the other contestants get 34 and 31 percent respectively. Although two-thirds of the votes in this example have supported other candidates, the plurality of votes is decisive.

In this system, the party share of parliamentary seats or their share of the popular vote does not count for the formation of government. The government may also be elected without an all out plurality of votes as long as it has the parliamentary majority. ${ }^{18}$ A "manufactured majority" is thereby created, in effect exaggerating the share of seats for the leading party in order to produce an effective working parliamentary majority for the government, while

${ }^{13}$ Pippa Norris (1997), "Choosing Electoral Systems: Proportional, Majoritarian and Mixed Systems", International Political Science Review, Vol. 18, No. 3, Contrasting Political Institutions (July 1997), p. 298.

${ }^{14}$ Id, p. 299

${ }^{15}$ Ibid.

${ }^{16}$ Ibid.

${ }^{17} \mathrm{Id}, 299-301$

${ }^{18}$ Ibid, See also, Ram Mudambi et. al., Plurality versus Proportional Representation: An Analysis of Sicilian Elections, Public choice, Vol. 86, No. 3/4, pp. 341-357 
simultaneously penalizing minor parties, especially those whose support is spatially dispersed.

The simple plurality voting system focuses on effective governance, not representation of all minority views. As Norris observes:

the country is divided into territorial single member constituencies, voters within each constituency cast a single ballot for one candidate, the candidate with the largest share of the vote in each district assumes the seat of the office; and in turn the party with an overall majority of seat forms the government. ${ }^{19}$

\section{b) Second ballot/ majority run-offs system}

This system tries to ensure that the winning candidate gets an overall majority of votes. Candidates obtaining an absolute majority of votes $(50+$ percent) in the first round are declared elected. ${ }^{20}$ If this is not the case, a second round run-off is held between the top two candidates who got the highest number of votes. The aim of run-off election is to consolidate support behind the victor, and to encourage broad cross party coalition-building and alliances in the final stages of the campaign. ${ }^{21}$

\section{c) Alternative vote}

Another majoritarian system is the "alternative vote" in which the voters rank their preferences among candidates instead of a simple " $\mathrm{X}$ " mark on their choice. In order to win, candidates need an absolute majority of votes. Where no candidate gets over 50 percent after first preferences are counted, then the candidate at the bottom of the pile with the lowest share of the vote is eliminated, and the votes are redistributed amongst the other candidates. ${ }^{22}$ The process henceforth continues until an absolute majority is secured. "This process translates a close lead into a more decisive majority of seats for the leading party however, systematically discriminating against those of the bottom of the poll in order to promote effective government for the winner". ${ }^{23}$

\footnotetext{
${ }^{19}$ Norris, supra note 13, p. 299-301

${ }^{20}$ David T. Canon (1999), "Electoral Systems and the Representation of Minority Interests in Legislatures", Legislative Studies Quarterly, Vol. 24 No. 23 pp 335-339

${ }^{21}$ Ibid.

${ }^{22}$ Norris, supra note 13, p. 299-301.

${ }^{23}$ Ibid.
} 


\subsubsection{Proportional representation}

\section{Party lists system}

Where majoritarian systems emphasize governability, proportional systems focus on the inclusion of minority voices. ${ }^{24}$ Proportional electoral systems based on party lists in multi-member constituencies are widespread throughout the world. The principle of proportional representation is that the seats in a constituency are divided according to the number of votes cast for party lists, but there are considerable variations in how this is implemented in different systems. $^{25}$

Party lists may be open, as in Norway, Finland, The Netherlands, and Italy. Under this system, "voters can express preferences for particular candidates within the list"; or they may be closed "as in Israel, Portugal, Spain, and Germany, in which case voters can only select the party, and the ranking of candidates is determined by the political party". ${ }^{26}$ The rank order on the party list determines which candidates are elected, for example, the top ten to fifteen names.

Party lists may also be national "as in Israel, where all the country is one constituency divided into 120 seats. But most party lists are regional, as in Belgium where there are seven regions each sub-divided into between 2 and 34 seats". ${ }^{27}$ The electoral formula varies among systems. Votes can be allocated to seats based on the highest averages method. This requires the number of votes for each party to be divided successively by a series of divisors, and seats are allocated to parties that secure the highest resulting quotient, up to the total number of seats available. ${ }^{28}$

There are a number of formulas available to undertake the task of dividing and allocating seats. "The most widely used is the d'Hondt formula, using divisors (such as 1, 2, 3, etc.)". ${ }^{29}$ In contrast, the 'pure' Sainte-Lague method divides the votes with odd numbers $(1,3,5,7$, etc.). The 'modified' SainteLague replaces the first divisor by 1.4 but is otherwise identical to the pure version. Another option is the largest remainder method, which uses a minimum quota calculated in a number of ways. In the Hare quota, used in Denmark and

${ }^{24}$ Burt L. Monroe (1995), "Fully Proportional Representation", The American Political Science Review, Vol. 89, No. 4, p. 925-927.

${ }^{25}$ Ibid.

${ }^{26}$ Norris, supra note 13, p. 303.

${ }^{27}$ Ibid.

${ }^{28}$ Ibid.

${ }^{29}$ See generally. Michael Gallagher (1992), "Comparing Proportional Representation Electoral Systems: Quotas, Thresholds, Paradoxes and Majorities”, British Journal of Political Science, Vol. 22, No. 4, (October 1992), p. 469-496. 
Costa Rica, "the total number of valid votes in each constituency is divided by the total number of seats" to be allocated. The Droop quota, used in South Africa and Greece, "raises the divisor by the number of seats plus one, producing a slightly less proportional result". 30

\subsubsection{Semi-proportional systems}

\section{a) Cumulative and limited vote}

Semi-proportional systems provide another option, including the cumulative vote, where citizens are given as many votes as representatives, and where votes can be cumulated on a single candidate. ${ }^{31}$ In contrast to this, there is also the limited vote, which somehow is similar to the cumulative vote, but voters are given fewer votes than the number of members to be elected. ${ }^{32}$

\section{b) Single Transferable Vote}

The system in this category divides the country into multi-member constituencies in which each constituency will have four or five representatives. Parties put forward as many candidates as they think could win in each constituency. Voters rank their preferences among candidates $(1,2,3,4 \ldots)$. The total number of votes is counted, and then this total is divided by the number of seats in the constituency to produce a quota. To be elected, candidates must reach the minimum quota. ${ }^{33}$ "When the first preferences are counted, if no candidate reaches the quota, then the person with the least number of votes is eliminated, and their votes are redistributed according to second preferences. This process continues until all seats are filled". ${ }^{34}$

\subsubsection{Mixed systems}

Many arrangements such as those adopted in Italy, New Zealand, and Russia, use mixed systems with variation in designs. ${ }^{35}$ The Additional Member System used in Germany combines single-member and party list constituencies. Electors have two votes. "Half the members of the Bundestag are elected in singlemember constituencies based on a simple plurality of votes". ${ }^{36}$ The remaining MPs are elected from closed party lists in each region. "Parties which receive

${ }^{30}$ Ibid.

${ }^{31}$ Id, 302.

${ }^{32}$ Ibid.

${ }^{33}$ Id, p. 303.

${ }^{34}$ Ibid.

${ }^{35}$ Norris, supra note 13, p. 303, See also, Gary, W. Cox and Mattehew Soberg Shugart (1996), "Strategic Voting Under Proportional Representation", Journal of Law, Economics and Organization, Vol. 12, No. 2, (October 1996), pp. 299-324.

${ }^{36}$ Ibid. 
less than a specified minimum threshold of list votes ( 5 percent) are not entitled to any seats". 37

\subsection{An Overview of the Ethiopian Approach}

Article 56 of the Constitution of the Federal Democratic Republic of Ethiopia ${ }^{38}$ provides that "a Political Party or a Coalition of Political Parties that has the greatest number of seats in the House of People's Representatives [HoPR] shall form the executive and lead it". The Constitution further stipulates that members of the HoPR shall be elected from candidates in each electoral district by a plurality of the votes cast. ${ }^{39}$

This has further been corroborated by the amended Electoral Law of Ethiopia, which states that "a Candidate who received more votes than other Candidates within a Constituency shall be declared the winner". ${ }^{40}$ Therefore Ethiopia follows the plurality system under which the candidate who receives more votes than other competitors within a constituency is declared the winner. This applies to all elections conducted in Ethiopia which include: "General Election, Local Election, By-Election, Re-election and Referendum". ${ }^{4}$

General Elections are conducted to elect members of the HoPR or State Councils conducted every five Years. ${ }^{42}$ These elections "shall be conducted throughout the country simultaneously. However, where the National Electoral Board finds it necessary and the House of Peoples' Representatives so decides, it may be conducted at different times". ${ }^{43}$ In general elections, "only a single representative shall be elected to the Federal House of Peoples' Representatives from a constituency". 44

Local Elections are held at Zonal, Woreda, City Municipality and Sub-City or Kebele council levels. "The number of representatives elected in a

${ }^{37}$ Ibid.

${ }^{38}$ Proclamation No. 1/1995, Proclamation of the Constitution of the Federal Democratic Republic of Ethiopia, Federal Negarit Gazeta, 1st Year No.1, Addis Ababa-2 $1^{\text {st }}$ August, 1995, adopted on $8^{\text {th }}$ of December 1994 and came into force $21^{\text {st }}$ August 1995.

${ }^{39}$ Id, Article 54(2)

${ }^{40}$ Proclamation No 532/2007, The Amended Electoral Law of Ethiopia Proclamation, Federal Negarit Gazeta, $13^{\text {th }}$ Year, No. 53, Addis Ababa, $25^{\text {th }}$ June 2007, Article 25

${ }^{41}$ Proclamation No 532/2007, Article 27.

${ }^{42} \mathrm{Id}$, Article 28.

${ }^{43} \mathrm{Id}$, Article 28(2).

${ }^{44}$ Id, Article 28(3).

${ }^{45}$ Id, Article 29(1). 
constituency for a local election shall be determined by laws of Regional States on the basis of the type of election and the number of seats in each council". 46 The time for local elections "shall be determined in accordance with the laws of Regional States". ${ }^{47}$ Local elections are conducted based on regulations and directives issued by the Board in accordance with the electoral proclamation. ${ }^{48}$

By-election is conducted when "the councils at different levels request the Board to replace council members whose mandates are terminated due to various reasons"; 49 or when "a request for recall lodged in accordance with the law is accepted". ${ }^{50}$ Moreover, it is a common practice to hold re-elections, mostly when there are election irregularities and complaints by the party or parties concerned. ${ }^{51}$ Re-election will be conducted when the Board decides in accordance with Article 7 (10) of the Proclamation; and where candidates receive equal votes in accordance with Article 76(3) of the Proclamation and where it becomes difficult to determine the winner. ${ }^{52}$

\section{Antecedents to the Ethnicization of Politics in Ethiopia}

Ethiopia has a long history of statehood with the ancient civilizations of the Abyssinian, Axumite and the Zagwe empires. ${ }^{53}$ However, the borders of the present day Ethiopia were mainly demarcated by the end of the $19^{\text {th }}$ century and early $20^{\text {th }}$ century. ${ }^{54}$ The process of centralization of state power which began since the reign of Emperor Tewodros II in the 1850's marks the beginning of Ethiopia's nation (empire) building. The subsequent rulers of the country pursued the same path. ${ }^{55}$

${ }^{46} \mathrm{Id}$, Article 29(2).

${ }^{47} \mathrm{Id}$, Article 29(3).

${ }^{48}$ Id, Article 29(4).

${ }^{49} \mathrm{Id}$, Article 30(1)(a).

${ }^{50} \mathrm{Id}$, Article 30(1)(b).

${ }^{51}$ Id, Article 31.

${ }^{52} \mathrm{Id}$, Article 30(1)(a) \& (b)

${ }^{53}$ Kidane Mengisteab, New approaches to State Building in Africa: The Case of Ethiopia's Ethnic-Based Federalism, African Studies Review, Vol. 40, No 3, (Dec 1997), p.119.

${ }^{54}$ See generally, Merera Gudina (2006), "Contradictory Interpretations of Ethiopian History: The Need for a New Consensus" in David Turton (ed.) Ethnic Federalism: The Ethiopian Experience in Comparative Perspective (James Curry, Oxford).

${ }^{55}$ Before the coming into power of Emperor Tewodros, the country had a noncentralized system of governance on what was termed as the reign of the Zamana Masafent; Assefa Fiseha (2007), Federalism and the Accommodation of Diversity in Ethiopia: A Comparative Study, (Rev.edn, Addis Ababa Artistic Printing Enterprise), p. 16. 
The formation of the modern Ethiopian state can be described as involving three processes: "the centralization of power, the territorial expansion of the Shewan rulers and the European expansion in pursuit of colonizing Africa". ${ }^{56}$ The nation building strategy employed by many of the Ethiopian rulers was mainly concerned with centralizing state power and conquering and expanding territory which eventually gave the present day Ethiopia its current geographic and demographic shape. Especially, the territorial expansion of Menelik II towards the south, east, and west transferred the relatively homogenous Abyssinian Empire into a mosaic of different ethno-linguistic groups and diversified culture.

Ethnicity, which is now the sole organizing principle of political power, was considered a taboo during this period let alone to be taken as a means of political organization and mass mobilization. ${ }^{57}$ But this taboo was broken through the struggle of the Ethiopian student movement which, inter alia, addressed "the question of Nationalities". 58 The popular revolution of 1974 finally deposed the Emperor from power through the machinery of his own military and the state was made secular. ${ }^{59}$

The Provisional Military Administrative Council (PMAC), otherwise known as the Derg, took advantage of the revolution and ascended to power. The Derg promised the equality of all nationalities, a promise that was far from being realized. ${ }^{60}$ With the motto Ethiopia Tiqdem (Ethiopia First), the Derg pledged to maintain the established unitary character of the state and proclaimed Ethiopia's indivisible unity. Promoting ethnic identity was then found to be a threat to the unity of the state; and in the face of various ethnic based armed movements fighting the Derg, the issue was further pushed aside. The Derg, which was strongly inspired by the ideas of the Ethiopian student movement, chose the Marxist/Leninist path. The country's problems were expressed and reduced as class antagonism rather than ethnic/nationalist. ${ }^{61}$ It was this position of the Derg

${ }^{56}$ Teshale Tibebu (1995), The Making of Modern Ethiopia 1896-1974, (Lawrence Vile, NI: The Red Sea Press, Inc,), p. 37.

${ }^{57}$ Ibid.

${ }^{58}$ Bahru Zewde (2001), A History of Modern Ethiopia 1855-1991, $2^{\text {nd }}$ ed. (Athens, Ohio: Ohio University Press,), p. 225.

${ }^{59}$ Teshale Tibebu, supra note 56, p. 167.

${ }^{60}$ Equality at the time meant the end of cultural subordination and the freedom to exercise ones culture, but not the autonomy and self-government of the nationalities. See, John Markakis (2003), Ethnic Conflict in Pre-Federal Ethiopia, paper presented at the $1^{\text {st }}$ National Conference on Federalism, Conflict and Peace Building, May 5-7, 2003 , p.10.

${ }^{61}$ John Young (1997), Peasant Revolution in Ethiopia-The Tigray's People Liberation Front (Cambridge University Press), p. 61. 
that led to a further strengthening of the ethnic based movements which started armed struggle immediately after 1974.

As a result, the Derg came under increasing pressure from regional and ethnic movements. The intensification of ethnic (civil) wars in the country, the increasing resistance to military rule and the rise of militant regional and ethnic opposition movements compelled it to consider some kind of decentralization and seek a constitutional solution. ${ }^{62}$ The Institute of Nationalities was established whose main task was to draft a Constitution which will reflect the ethnic makeup of the country with viable administrative divisions. ${ }^{63}$ Ethnicity in Ethiopia reached its political maturity generally during this period of Military rule. The major reasons include the growth and politicization of the intelligentsia (especially the leftist ideology), promotion of ethnic-cultural emancipation, the end of divinity and reference to the Solomonic dynasty to legitimize political power, the proclamations which announced the equality of all groups and the right of nationalities to self-government, the mass literacy campaign and the introduction of local languages, the accounting of linguistic and religious diversity in the population census and the constitutional provisions of autonomous regions. ${ }^{64}$

Towards the end of its reign, the Derg granted autonomy to carefully selected provinces distressed by ethnic and nationalist strife. ${ }^{65}$ But this was an action taken very late in time to reverse the ethnic insurgencies and political instability of the country. Ethnic/nationalist movements were gaining prominence over the Derg.

From among the many ethnic based resistance movements, the one that played the decisive role in the ultimate demise of the Derg was the TPLF (Tigray Peoples Liberation Front). It was established in 1975 by students who were strongly influenced by the Ethiopian student movement and thus by the

${ }^{62}$ Mehret Ayenew, Decentralization in Ethiopia: Two Case studies on Devolution of power and Responsibilities to local government in Bahru Zewde and Siegfried Pausewang (eds.) 2002, Ethiopia: The Challenge of Democracy from Below, Nordiska Afrikainstitutet, (Uppsala and Forum of Social Studies, Addis Ababa) pp. 134-135.

${ }^{63}$ The Institute for the Study of Ethiopian Nationalities was a political research bureau that did research work under the military regime. Most of the results from the institute's research have been directly taken over under the post 1991 regime in the restructuring of the country via ethnicity. See John G. Abbink (1998), New Configurations of Ethiopian Ethnicity: The Challenge of the South, Northeast African Studies Vol. 5, No.1, pp. 62-63.

${ }^{64}$ John Markakis, Supra note 60, p. 20.

${ }^{65}$ For a discussion of the administrative divisions, their powers and boundaries at the time See, Assefa Fiseha, supra note 55, pp. 43-46. 
ideas about ethnic problems. ${ }^{66}$ In the course of the liberation struggle, the TPLF decided to widen its objectives and to extend its actions to areas outside Tigray. ${ }^{67}$ Ultimately, the EPRDF (Ethiopian Peoples Revolutionary Democratic Front) which is a coalition of ethnically based parties was formed.

Finally, the ethnic/nationalist opposition movements were successful in overthrowing the repressive Derg dictatorship. Eventually, EPRDF proclaimed its intentions of doing away with the past and creating a new mode of state building in which the central agenda is ethnicity. A national conference was set up for this purpose in Addis Ababa form July 1-5, 1991 and it led to the signing of the Transitional Period Charter in which ethnic diversity and the right to selfdetermination for all ethnic groups were recognized as core aspirations.

The EPRDF upheld ethnic issues as its central agenda during the transitional period which was followed by the promulgation of the new Constitution which was built by a marriage of ethnicity and federalism. Ethnic criteria played the major (probably the only) role in the reorganization of the country. This can be seen directly from the fact that the 1995 Constitution establishes nine regional states that are largely delimited along ethno-linguistic lines. Indeed, the Ethiopian government has tried to realize a match between regional state delimitation and ethnic identity, which has relatively solved the problem of the different contending ethnic groups. On the other side of the spectrum, ethnicization of politics has also brought about new and unprecedented ethnic antagonisms and tension especially in the regional states. ${ }^{68}$

Federalism at the regional level, under the current ethnic federal structure is seriously questioned from the perspective of empowerment of the different resident ethnic groups especially minorities. The ethnically diversified character of the country is present at the regional state level as well. None of the ethnically framed nine regional states in the strictest sense can be termed as ethnically homogenous ones. This can simply be deduced from the fact that there exists more than eighty ethnic groups in the country but only nine regional states have so far been formed. To this effect, the Ethiopian approach of territorial accommodation of ethnic diversity has created a situation by which especially at the regional level - the regionally dominant group considers the region as its property, in effect, threatening the political aspirations of other ethnic groups, thereby resulting in their political relegation.

${ }^{66}$ See, Young, supra note 61, p. 61-65.

${ }^{67}$ Ibid.

${ }^{68}$ For an excellent articulation of the problems See, Yonatan Tesfaye Fessha and Christophe Van Der Beken (2013), "Ethnic Federalism and Internal Minorities: The Legal Protection of Internal Minorities In Ethiopia”, African Journal of International and Comparative Law, 21.1 , pp. 32-49. 


\section{The Electoral System and Minority Rights}

It is believed that minority rights can best be "achieved and articulated through a combination of majority sensitivity and minority inclusion". ${ }^{69}$ The inclusion of minorities in representative bodies is a necessary, if not sufficient, condition of conflict prevention and longer-term conflict management. "There is not a single case of peaceful and democratic conflict avoidance in which the minority community is excluded from legislative representation". ${ }^{70}$

Electoral systems are tools developed for organizing representative democracies. They are the mechanisms used to elect decision makers who represent citizens when societies become too large for every citizen to be involved in each decision that affects the community. ${ }^{71}$ However, elections can lead to uneven distribution of powers and most importantly to the marginalization and relegation of minority groups if they are not managed appropriately taking into consideration the specific needs of the electorate.

While there are some basic elements of participatory democracy present in all methods of electing leaders around the world, the details of electoral systems vary widely. ${ }^{72}$ The issue of adopting an electoral system largely depends upon the nature and character of the specific society. What works well in a homogenous society may not be so in multiethnic societies.

With regard to the protection of minorities, the electoral system may be used with two aims. "One is to ensure the adequate parliamentary representation of a minority, and the second is to increase the electoral influence of minority groups independently from representation" ${ }^{73}$ Adequate parliamentary representation may be ensured through the choice of an electoral system while guaranteed representation of minority groups (mostly provided by legislative guarantees) could be undertaken by reserving some seats for minority groups to increase minority representation outside of electoral competition.

As discussed in the previous section, two main types of electoral systems generally dominate the world. These are majority systems and the proportional representation system. While the first one is characterized by the winner takes all in which a relative majority is sufficient to be declared the winner, the second electoral system gives primacy to a close relationship between the votes

${ }^{69}$ Andrew Reynolds (2006), "Electoral Systems and the Protection and Participation of Minorities", Minority Rights Group International, p. 3.

${ }^{70}$ Ibid.

${ }^{71}$ Id , 8 .

${ }^{72}$ Ibid.

${ }^{73}$ J. A. Laponce (1957), "The Protection of Minorities by the Electoral System", The Western Political Quarterly, Vol. 10, No. 2 (June 1957), p. 321. 
cast and seats won proportionally. ${ }^{74}$ Electoral systems are generally defined and categorized with reference to representatives elected from each constituency district, the formula adopted (either plurality or proportionality of vote) and threshold of representation for parties or candidates (which can be determined by the law or by the number of seats). ${ }^{75}$

Ethiopia has adopted the "first-past-the-post" electoral system which simply states that one who receives the majority of votes within the electoral district is the winner. ${ }^{76}$ In practice, this means the one seat in each electoral district is won by the candidate who gets a simple comparable majority of votes in the district. In a country where the states are organized on ethnic lines and where none of these states are ethnically homogenous, the use of such electoral system runs the risk that the seat in each electoral district will be won by the candidate who represents the interest of the largest ethnic group in the district. This is particularly problematic for minorities that are to be found dispersed, which will eventually make them a minority in each electoral district.

In this regard, Horowitz maintains that "electoral systems have a huge role in fostering or retarding ethnic conflict". He argues that the "delimitation of constituencies, the electoral principle, the number of members per constituency, and the structure of the ballot have a potential impact on ethnic alignments, ethnic electoral appeals, multi-ethnic coalitions, the growth of extremist parties, and policy outcomes". ${ }^{77}$

Particularly, the electoral system harnessed to the goal of ethnic accommodation can be utilized to: fragment the support of one or more ethnic groups, especially a majority group, to prevent it from achieving permanent domination. This induces an ethnic group, especially a majority, to engage in inter-ethnic bargaining and encourage the formation of multiethnic coalitions. This consequently preserves "a measure of fluidity or multipolar balance among several groups to prevent bifurcation and the permanent exclusion of the resulting minority and reduce the disparity between votes won and seats won". ${ }^{78}$

Taking this as a background regarding the need for minority protection and the necessity of choosing an appropriate electoral system to be adopted, a brief discussion about ethnic group determination and minority rights ascertainment in the Ethiopian context is made in the following section.

\footnotetext{
${ }^{74}$ Andrew Reynolds, supra note 62, p. 8.

${ }^{75}$ Ibid.

${ }^{76}$ Proclamation No 532/2007, Article 25.

${ }^{77}$ Donald L. Horowitz (1985), Ethnic Groups in Conflict, University of California Press, p. 628.

${ }^{78} \mathrm{Id}, 632$.
} 


\section{Ethnic Group Determination and Minority Rights}

As Eide notes, the issue of minority "can only occur in pluralistic societies, defined as societies in which significant diversity and dissimilarities exist". ${ }^{79}$ Such issues "involve tensions between the state, on the one hand and religion, nationality, ethnicity, or culture, on the other". ${ }^{80}$ This predicament at the same time may take up two forms. The first is the case in which the state solely serves the purpose of majorities and represses minorities, while the second situation is the case by which the state is unwilling to impartially protect minorities. ${ }^{81}$

Minority rights were first recognized in international relations, as specific solutions to transboundary conflicts. It was only afterwards that they were transferred to the domestic level. ${ }^{82}$ Despite the long history of the discourse on the protection of minorities, the clarity of relevant international legal standards on minorities still remains unsatisfactory. ${ }^{83}$ This is mainly attributed to the fact that there exists no binding definition on the concept of a minority as the holder of minority rights. Even though there is no binding definition in the international arena, an attempt has been made by different scholars to determine its scope of application and its right holders.

The most widely accepted definition of a minority is forwarded by the United Nations Special Rapporteur Francesco Capotorti, who defines it as:

a 'group', numerically inferior to the rest of the population of a state, in a non dominant position, whose members being nationals of a state possess ethnic, religious or linguistic characteristics differing from those of the rest of the population and show, if only implicitly, a sense of solidarity, directed towards preserving their culture, traditions, religions or language. ${ }^{84}$

This definition of a minority illustrates that persons belonging to such minority groups have the right to self-determination. Conceptually, "persons belonging to ethnic, religious or linguistic minorities meet the criteria for consideration as people in the context of the right to internal self-determination". 85 Such

\footnotetext{
${ }^{79}$ Asbjorn Eide (1990), "Minority Situations: In Search of Peaceful and Constructive Solutions”, 66 Notre Dame L. Rev., p. 132.

${ }^{80}$ Ibid.

${ }^{81}$ See, Ibid.

${ }^{82}$ Ibid, p. 133.

${ }^{83}$ Jungwon Park (2006), "Integration of Peoples and Minorities: An Approach to the Conceptual Problem of Peoples and Minorities with Reference to Self Determination under International law”, 13 Int'l J. on Minority and Group Rts., p. 69.

${ }^{84}$ Francesco Capotorti (1979), Study on the Rights of Persons Belonging to Ethnic, Religious and Linguistic Minorities, UN Doc. E/CN.4/Sub.2/384/Rev.I., Paragraph 568

${ }^{85}$ Park, supra note 83, p. 93.
} 
understanding is paramount in expounding the rights of minorities because the effective realization of minority rights becomes possible and more secure with the normative basis of the right to self-determination. ${ }^{86}$ Deschnes added to the above definition one important factor, namely that "the minority's aim is to achieve equality with the majority in fact and in law". ${ }^{87}$

Even though it is not the purpose of this article to engage in the controversies of accurate definition for minorities, it will be worth commenting on the requirement that the group be numerically inferior has often been questioned as misguiding. ${ }^{88}$ No regional or international consensus has been reached toward establishing a universally acceptable notion of what constitutes a minority. Minority rights group international asserts that regardless of its demographic makeup, a group that is disempowered may be classified as a minority. ${ }^{89}$ Therefore, as most commentators on the subject agree, the focus should be more on the non-dominant character of the group in which minorities are seen as the subordinate elements of the state..$^{90}$

The enormous divergence in the numerical sizes of the various ethnic groups of Ethiopia, together with the lack of a majority at the country level, would obviously lead to the assumption that no ethnic or linguistic group can be considered as a majority at the federal level in the country. ${ }^{91}$ Apart from employing the term minority nationalities, the FDRE Constitution has not defined the term minority and it did not also identify which groups qualify as minorities. Rather, it simply states the defining criterion for an ethnic group in Article 39 as "nations, nationalities and peoples." It defines ethnic groups (nation's nationalities and peoples) as "a group of people who have or share a large measure of a common culture or similar custom, mutual intelligibility of language, belief in a common or related identity, a common psychological makeup, and an identifiable, predominantly contiguous territory". ${ }^{2}$

\footnotetext{
${ }^{86}$ Ibid.

${ }^{87}$ Shane Daray (2002), “The Rights of Minorities in States of Emergency”, 9 Int'l J. on Minority and Group Rts. p. 346.

${ }^{88}$ In this regard the situation of the people of Oromo and that of white South Africans are typical examples respectively.

${ }^{89}$ Stephanie Kodish, "Balancing Representation: Special Representation Mechanisms Addressing the Imbalance of Marginalized Voices in African Legislatures", 30 Sufflok Transnat'l L. Rev. (2006-2007), p. 21

${ }^{90}$ See, Id, p. 34.

${ }^{91}$ Aberra Dagafa (2008), "The Scope of Rights of National Minorities under the Constitution of the Federal Democratic Republic of Ethiopia", Series on Ethiopian Constitutional law,Vol.1, pp. 104-105.

92 Article 39(5) of the FDRE Constitution.
} 
This seems to signify that the Constitution subscribes to the primordial ideas of ethnicity. ${ }^{93}$ Since the whole population of the country is seen as composed of nations, nationalities and peoples as defined above, it means that every citizen must belong to an ethnic group and define himself/herself along ethnic lines. ${ }^{94}$ The Constitution also seems to have taken the presumption that ethnic groups live in geographically concentrated areas, that the regional states are inhabited by ethnic groups. This presupposes that they are homogenous and have the same interest and are equated with political units even though these assertions are not in conformity with the reality of the Ethiopian society. ${ }^{95}$

\subsection{Minority Determination and Setting up of Electoral Constituencies}

Neither ethnic nor linguistic minorities have been defined specifically under the 1995 FDRE Constitution. Other than setting the standard criteria for designating a nation, a nationality or people, the Constitution has not made any reference to the exact number of persons required by such a formulation. One may argue therefore that all nations, nationalities and peoples of Ethiopia are entitled to enjoy equally all the rights guaranteed by the Constitution regardless of their numerical size. $^{96}$

But under the Transitional Period Charter, the term "Nation" or "Nationality" was defined in Proclamation No 7/1992 as referring to a "people living in the same geographical area and having a common language and a common psychological makeup or identity". 97 The Proclamation defined "minority nationality' as a nationality or people which cannot establish its own Woreda self government because of the small number of its population. ${ }^{98}$

Later on, Article 54(3) of the FDRE Constitution inserted the term "minority nationalities or peoples" without defining what is meant by the term. After the adoption of the Constitution, the term minority nationality was defined in

${ }^{93}$ See, Lovise Aalen (2006), "Ethnic Federalism and Self-determination for Nationalities in a Semi-Authoritarian State: The Case of Ethiopia", 13 Int'l .J. on Minority and Group Rts., pp. 246-247.

${ }^{94} \mathrm{Id}, 247$.

${ }^{95}$ Ibid.

${ }^{96}$ Aberra Dagafa , supra note 91, p. 101-102.

${ }^{97}$ Proclamation No 7/1992, A Proclamation to Provide for the Establishment of National /Regional Self-governments, Negarit Gazeta $51^{\text {st }}$ Year No 2, Addis Ababa, $14^{\text {th }}$ January 1992, Article 2(7).

${ }^{98}$ Id, Article 2(6); Cf Proclamation No 11/1992, A Proclamation to Provide for the Establishment of the National Regional and Woreda Councils Members Election Commission, Negarit Gazeta, $51^{\text {st }}$ Year, No. 6, $8^{\text {th }}$ February 1992, Article 2(5) defined minority in a similar way. 
Proclamation 111/1995 as "a community determined by the council of representatives or its successor to be of a comparatively smaller size of population than that of other nations/nationalities". ${ }^{99}$

When one analyzes the definitions given under the preceding proclamations in light of the Article 54(3) of the Constitution, it seems that 'minority nationality' refers merely to those particular ethnic groups that do not have sufficient number of people to make up a constituency so as to have their own representatives in the House of Peoples Representatives (HoPR). Thus, as per Article 15(2) of Proclamation No. 111/1995, since each electoral constituency is made up of 100,000 inhabitants, an ethnic group below such a requirement may be considered as a 'minority nationality' and accordingly, the HoPR may permit such group to have special representation in the HoPR. ${ }^{100}$

However, Proclamation No. 111/1995 has been replaced by Proclamation No. 532/2007. Unlike Proclamation No. 111/1995, the new proclamation does not base an electoral constituency on a fixed number of population but rather states that the number of constituencies is to be determined based on the population census of the country. ${ }^{101}$ Electoral constituencies now do not have a fixed numerical threshold. Instead, considerations are made generally taking into account the population size of the country.

Therefore, it can be discerned that there is no minimum numerical requirement that an ethnic group should meet to be considered a minority. This proclamation has not defined what is meant by minority nationalities and secondly, it has left the issue of determining the numerical size of an electoral constituency based on the population size of the country rather than setting a predetermined figure. Nevertheless, one can deduce that, a minority nationality is one which cannot establish its own electoral constituency whatever the number of the group. The Proclamation addresses the issue of ascertaining minority nationalities using a modality which is different from its predecessor. It states that "minority nationalities which require special representation shall be determined on the basis of clear criteria" set in advance by the House of Federation. ${ }^{102}$ However, what is meant by 'clear criteria' is ambiguous.

One may argue that a nation, nationality and people should refer only to those groups that can form their own electoral constituency. This would in effect mean that minority nationalities are within the emblem of nation, nationality or people. While the former can exercise the right to self-determination, the latter

\footnotetext{
99 See, Proclamation No 111/1995, A Proclamation to Make the Electoral Law of Ethiopia Conform to the Constitution of the Federal Democratic Republic of Ethiopia, Negarit Gazeta, 54 ${ }^{\text {th }}$ Year, No. 9, $23^{\text {rd }}$ February 1995 Article 2(3).

${ }^{100}$ See, Aberra Dagafa , supra note 91, p. 101-102.

101 See, Proclamation No 532/2007, Article 20(1) (b).

102 See, Proclamation No 532/2007, Article 20 (1) (d).
} 
are not capable of exercising such right due to their numerical inferiority except through the mechanism of special representation.

In a similar fashion, it can be argued that, minority groups are those which are not represented in the House of Federation (HoF) because of their inability to fulfill the requirement of one million population. ${ }^{103}$ Hence, an ethnic group that constitutes less than one million people could also be considered as minority at least for the purpose of political representation. During the 1994 population and housing census of Ethiopia, some 80 ethnic groups were identified but the members of the House of Federation at the time were $64 .{ }^{104}$ Hence, the constitutional guarantee that each nation, nationality or people shall be represented by a single member has not been put into practice. Due to the practical limitation that every ethnic group is not represented in the house, every decision is taken on a majority basis. ${ }^{105}$ The absence of veto powers for minority nationalities, even in matters strictly affecting their rights, makes it difficult for the House of Federation to adequately accommodate the rights of minorities. As the following paragraphs indicate, the issue of political participation of minorities at the federal level also deserves attention.

\subsection{The Right to Political Participation of Ethnic Groups at the Federal Level}

If one looks at the issue of the representation of minorities at the federal level in light of the need for political bargaining power for their rights, the seats guaranteed for them in the Constitution will in effect play no role. Four ethnic groups (Amhara, Oromo, Somali, and Tigray) together form an overwhelming majority. If we see the case of the HoPR, elections to the house are conducted by means of general and direct elections under the first past the post electoral system. ${ }^{106}$ However, Article 54(3) of the Constitution provides for a guarantee of representation for minority nationalities and peoples by stipulating that at least 20 seats are reserved for these minorities out of the maximum number of 550 seats. In accordance with the Constitution, unless otherwise provided, "all decisions of the house shall be by a majority vote of members present and voting" ${ }^{107}$ The quorum requirement will be fulfilled upon the presence of more than half of the members of the house. ${ }^{108}$ In effect, the combined presence of the

\footnotetext{
103 Assefa Fishea, supra note 55, p. 275.

${ }^{104}$ See, Aberra Dagafa , supra note 91, p. 96-100, 134-135.

105 Article 64 (1) of the FDRE Constitution.

106 See Article 54(2) of the FDRE Constitution.

107 Article 59(1) of the FDRE Constitution.

${ }^{108}$ Article 58(1) of the FDRE Constitution.
} 
four big nationalities in the house will suffice to legislate even in matters that affect the interests of other ethnic groups.

The same reasoning applies to the House of Federation which is also based on majoritarian rule because all decisions of the House require the approval of majority members present and voting. The quorum requirement is the presence at a meeting of two thirds of the members of the House. ${ }^{109}$ Unlike the HoPR, there are no guarantee seats to minority nationalities in the HoF. Each nation and people will have at least one member and will additionally be represented by one additional representative for each additional one million people. ${ }^{110}$ The larger the population size of an ethnic group, the higher the representation it will secure in the house and the higher is the risk of minorities being engulfed by the populous ethnic groups in the decision making process.

\subsection{Regional Minorities: General Overview}

There are more than eighty ethnic groups in the country, but nine regional states have been created. Not surprisingly, none of the nine regional states are ethnically homogenous. ${ }^{111}$ The Ethiopian federal system seems to have taken the assumption that every ethnic group inhabits a territorially defined geographical area.

Since the main objective of restructuring the country after 1991 was to address the issue of nationalities or 'the nationality question', ethnic groups (at least the major ones) were assigned specific regional states by which they are able to exercise their right of self-determination. In the process, the issues that arise from sub-national ethno-cultural diversity seem to have been overlooked.

Even though attempt has been made to match territorial autonomy with ethnic identity thereby creating homogenous states, the outcome is not as expected. All regional states of the Ethiopian federation, to a lesser or greater extent have an ethnically diverse population. The ethnic diversity that characterizes the federal level is also present at the regional level. Therefore, one may conclude that a perfect match between ethnic groups and territorial autonomy has not materialized as the drafters of the Constitution wished (and perhaps it may be impossible to do so). Rather, the act of drawing regional boundaries based on the major ethnic groups gave rise to the creation of minority ethnic groups in each of these regions.

\footnotetext{
109 Article 64(1) of the FDRE Constitution.

110 Article 61(1) of the FDRE Constitution.

111 Tsegaye Regassa, State Constitutions a Preliminary Observation, available at $<$ http://camlaw.rutgers.edu/statecon/subpapers/regassa.pdf. > Accessed on march 16, 2009.
} 
In terms of numerical superiority and political dominance of an ethnic group, the nine regional states can be classified in four categories. In the first category are five regional states in which the Tigray, Afar, Amhara, Oromo and Somali ethnic groups are dominant numerically as well as politically. ${ }^{112}$ In the second category is the state of the southern nations, nationalities and peoples with an amalgam of different ethnic groups. Although there is no numerical majority, it seems that not all ethnic groups within the regional state have equitable share in government power. In the third category is the regional state of Harar. Aalen considers it as "an anomaly in the Ethiopian federation". 113 The Harari regional state is formed in favor of the Harari ethnic group. What is surprising in this regional state is that the Harari are a numerical minority. However, they occupy the key political positions thereby making them politically dominant over other ethnic groups within the region.

In the fourth category are the multiethnic regional states of Benishangul Gumuz and Gambella. In the case of the former, the name of the region refers to the politically dominant ethnic groups of Berta and Gumuz. ${ }^{114}$ While no single ethnic group is a numerical majority in the region, the politically dominant indigenous nationalities numerically added together constitute a slight majority over other ethnic groups. In the case of the latter, the name Gambella does not have an ethnic correlation within members of the ethnic groups residing in the region. It is rather accorded a territorial name and not an ethnic one. The indigenous nationalities constitute a slight numerical majority over other ethnic groups and are also the politically dominant ones.

It is from the above modalities of regional state formations that the concept of regional minorities emanates. Thus, minority status at the regional level is determined due to lack of numerical majority as well as political dominance over the others or owing to the absence of political dominance irrespective of numerical foundations. Regional minorities under the Ethiopian context may be described as those groups which differ from the regionally dominant ethnic group. This dominance may be expressed in terms of political empowerment and/or numerical majority of an ethnic group. For example, the Amhara, Tigray, Afar, Somali and Oromo ethnic groups are the numerical majority as well as the politically dominant groups in their respective regions. In case of Harar, the numerical minority is the politically dominant section of the society, while in

${ }^{112}$ See generally, Christophe Van der Beken (2007), "Ethiopia: Constitutional Protection of Ethnic Minorities at the regional level", Afrika Focus, Vol. 20, No. 1-2,

${ }^{113}$ Lovise Aalen (2002), Ethnic Federalism in a Dominant party State: The Ethiopian Experience 1991-2000, Bergen: Chr. Michelesen Institute, , p. 90

${ }^{114}$ It is worth noting here that there are five indigenous Nationalities identified in the region. These are the Berta, Gumuz, Shinasha, Mao, and Como. 
Benishangul and Gambella there is no single numerical majority, though the indigenous nationalities are the politically dominant sections.

With the exception of a few, the regional states are carved in favor of the majority ethnic group. Hence, an Amhara who belongs to a majority in his own state will find himself reduced to minority status in Oromia region and viceversa. This problem has not been dealt within the Constitution and what is worse, the exercise of government power in the regional states has been exclusionary for these minorities. The dominant (majority) ethnic group considers itself to be the owner of the regional state while other ethnic groups are relegated. ${ }^{115}$ This is exacerbated by the electoral law due to its adoption of the plurality system for a multi-ethnic country. This setting is described by some scholars as a condition of creating 'local tyranny'. ${ }^{116}$

The denial of rights of regional minorities varies from being marginalized politically to economic relegation. ${ }^{117}$ The following section deals with these issues, particularly with respect to the political rights of regional minorities under the current electoral system.

\section{The Right to Political Participation and Adequate Representation of Regional Minorities in Ethiopia}

The concept of political participation, as part of minority rights, is premised on two major arguments. The first argument is that, the right to political participation of minorities "cannot be effectively ensured unless the minority actively partakes in the political decision-making process which governs the protection of its rights". ${ }^{118}$ Secondly, "minorities run the risk of being excluded from the political system without special protective measures" especially in countries where most people likely vote for parties or candidates from their own ethnic groups. ${ }^{119}$ Furthermore, a number of approaches to democracy run the risk of permanently excluding minorities. Most obviously, the British style 'first

\footnotetext{
115 The Constitution of the regional state of Oromia under its Article 8 which rests sovereign power solely on the Oromo people is an excellent account to this.

${ }^{116}$ Assefa Fiseha, "Theory versus Practice in the Implementation of Ethiopia's Ethnic Federalism", in David Turton (ed.) 2006, Ethnic Federalism: The Ethiopian Experience in Comparative Perspective (James Curry, Oxford), p. 136.

${ }^{117}$ Yonatan Tesfaye Fessha and Christophe Van Der Beken, supra note 68, pp. 32-49.

${ }^{118}$ Florian Bieber, Balancing Political Participation and Minority Rights: The Experience of the former Yugoslavia, available at $<$ www.netrouz.com/filedownload/florian/pdf.> Accessed on December 28, 2008. ${ }^{119}$ Ibid.
} 
past the post' electoral system which Ethiopia has endorsed has the feature of excluding minorities from representation within an electoral district. ${ }^{120}$

The Ethiopian federal system's attempt to create ethnically homogenous subnational units has been frustrated by the existence of regional minorities scattered and/or concentrated in every regional state. All the regional states of Ethiopia are no exception to this pursuit of creating ethnically homogenous units. Despite the multiethnic character of the regions, the political representation of regional minorities in the regional state's council has been problematic. For example, in the 2001 elections of Benishangul Gumuz, no representative from the non-indigenous communities ${ }^{121}$ was elected for the regional council and national parliament. ${ }^{122}$ Although $67 \%$ of the inhabitants in Assosa town, $43 \%$ in Assosa zone, 50\% in Metekel zone and 20\% in Kamashi Zone are from the nonindigenous groups. However, they have not been represented in zonal and regional government structures, regardless of their citizenship rights. ${ }^{123}$ By the year 2005, there were 99 representatives in the regional parliament. The three populous indigenous nationalities held the lion's share of seats in the regional parliament: the Berta had 41 seats, the Gumuz 35 and the Shinasha 11, the Mao and Como each held two seats. Only few leftover seats were taken up by the non-indigenous groups.

Moreover, these non-indigenous groups were severely curtailed in the exercise of their democratic rights to be elected in the regional legislative body, due to the electoral law of the country at the time, which stipulated that for an individual to be elected as a member of the regional state council he/she has to be proficient in one of the indigenous languages of the region.

The issue of political representation of the non-indigenous groups and the stipulation of the electoral laws has created bitter resentment amongst the nonindigenous groups leading to petition to the House of the Federation. "Some even requested that they be repatriated to their former place of residence as most of them were made to settle in the region due to the Derg's forced villagization and resettlement program". ${ }^{24}$

${ }^{120}$ Ibid.

${ }^{121}$ These people are those who mostly arrived in the region due to the Derg's program of villagization and resettlement. It also comprises of those who went to the region as migrant workers and established their livelihoods permanently in the region.

${ }^{122}$ Berhanu G Balacha, Divide and Rule: Ethnic Federalism in Benishangul Gumuz Region of Ethiopia, available at, $<$ www.ethiopolitic.com/pdfiles/divide and rule Dec 21.2007.pdf.> Accessed on June 14, 2009, p. 4.

${ }^{123}$ Ibid.

${ }^{124}$ Getachew Assefa, "Federalism and Legal Pluralism in Ethiopia: Reflections on their Impacts on the Protection of Human Rights" in Girmachew Alemu and Sisay Alemahu (eds.) 2008, The Constitutional Protection of Human Rights in Ethiopia: 


\subsection{The Demand for Adequate and Equitable Representation}

The demand for adequate representation and the right to share political power by regional minorities in the regional states has been a slow but a rising process since the restructuring of the country based on ethnicity as a whole after 1991 . This increasing claim reached its peak when Ethiopia's electoral law provided for the criterion of language as a fundamental pre-requisite for political candidature. The problem eventually surfaced in the regional state of Benishangul Gumuz, when the regional minorities submitted their petition to the House of Federation. The issue in brief involved a tension between the region's indigenous groups (Berta, Gumuz, Shinasha, Como and Mao) and that of the non-indigenous communities. ${ }^{125}$

The point of contention at the time was a decision by the regional state and the national election board, that for a person to be a candidate for a national or regional election, he/she should be able to speak at least one of the indigenous groups' languages of the region. ${ }^{126}$ Particularly, the Berta political party at the time insisted that in the Bambasi Woreda (district) of the Assosa Zone, opposition candidates of the non-indigenous groups should not be allowed to run for office for none of them are versed in the Berta language. The party then subsequently petitioned to the National Electoral Board that they be cancelled from the election. The Board gave its decision based on the direct application of Article 38 of Proclamation No. 111/1995 which was the electoral law in force at the time and banned those running for office who cannot speak the local vernacular. $^{127}$

The groups affected by the decision petitioned to the House of Federation that the decision of the Board violated their constitutional right to be elected which is granted to every citizen without any discrimination. They claimed that the wordings of Article 38(1) (b) of the Proclamation contravenes Article 38 of the FDRE Constitution, which grants every citizen the right to be elected without any discriminatory precondition attached to it. Hence, they demanded that the criterion of language be declared unconstitutional and null because it violates the provision of the Constitution. The following were the reliefs sought by the non-indigenous groups.

Challenges and Prospects, Ethiopian Human Rights Law Series, Vol.2 (Dec. 2008), pp. 12-14.

${ }^{125}$ Assefa Fiseha (2007), Constitutional Adjudication in Ethiopia, 1 Mizan Law Review, (June 2007), p. 23.

${ }^{126}$ This decision is premised on the argument that according to Proclamation No $111 / 1995$ Article 38(1) (b) one of the criteria for candidature is being versed with the vernacular of the region of intended candidature.

${ }^{127}$ Getachew Assefa, supra note, 124, p. 12-14. 
1. They demanded that they be fairly and equitably represented in the regional and national administrative organ hierarchies. It is interesting also to note that the petitioners claimed to be recognized as distinct ethno-national groups in the region along with the five indigenous groups. Accordingly, they asserted that their right to self-determination under Article 39 of the FDRE Constitution be respected.

2. They demanded a special administrative status in the region so that they will be able to exercise self governance, or

3. Alternatively, they requested repatriation to the regions or places where they can have their rights respected and be able to preserve and develop their culture and language. ${ }^{128}$

But, the House only considered the language requirement for constitutional interpretation and stated that "the House focuses on issues of electing and being elected as other demands are responded by the regional and other executive bodies". ${ }^{129}$ After having received advisory opinion from the Council of Constitutional Inquiry and professional recommendations, the House framed two issues for decision. ${ }^{130}$

1. Whether the language requirement to be eligible as a candidate under Article 38(1)(b) of Proclamation No. 111/1995 violates Article 38(1)(a) of the FDRE Constitution;

2. Whether the decision given by the Electoral Board is constitutional.

By a majority of 6 out of the 8 members, the advisory opinion of the Council of Constitutional Inquiry submitted to the House stated that Article 38(1)(b) of Proclamation No. 111/1995 is unconstitutional. Disregarding this opinion, the House opined on the first issue that knowing the local (official) language with which the state council performs its duties can duly be used as a criterion for election and it declared Article 38(1)(b) of the Proclamation as constitutional. With regard to the second issue, however, the $\mathrm{HoF}$ declared the Electoral Board's interpretation of the Proclamation unconstitutional because it required a candidate to be versed in one of the indigenous languages, particularly, the Berta language (one of the five indigenous languages spoken in the region) even though it is not the official language of the regional state. ${ }^{131}$

\footnotetext{
${ }^{128}$ Ibid.

${ }^{129}$ Decision of the House of Federation on 'Constitutional Dispute Concerning the Right to Elect and being Elected in Benishangul Gumuz Regional state, 13 March 2003, Available www.hofethiopia.org/HOF/HOF-constitutional-interpetation.htm

${ }^{130}$ Ibid.

${ }^{131}$ Ibid.
} 


\subsection{Language as a Legitimate Requirement or a Barrier?}

After the decision rendered by the HoF, the electoral law of the country underwent substantial amendments, the major one being Proclamation No. 532/2007, which under Article 45(1)(b) embodied a specific provision similar to the decision rendered by the House. ${ }^{132}$ The Proclamation pursued the idea that language should be used as a legitimate requirement. The formulation under this Proclamation took the working language of the region or the local vernacular as an alternative requirement. ${ }^{133}$ The decision of the House of the Federation on the one hand and the electoral law on the other were understood in two differing ways.

\section{a) In favour of the language requirement}

The argument in favour of the electoral law applauds the decision rendered by the House of Federation, as a decision which attempted to strike a balance between the concerns of the different ethnic groups. ${ }^{134}$ Assefa argues that "saying simply that the language requirement is discriminatory and unconstitutional will be missing the fundamental virtue of not only the Ethiopian Constitution, which is apparently based on the free will of nationalities, but also the values of federalism, unity in diversity". ${ }^{135}$

The other point worth considering in favour of the language requirement is that simple elimination of the language requirement for candidature will impair the rights of indigenous groups whose access to political power, the use of their language and associated cultural rights had been curtailed for long. "The very purpose in which the states of Harari, Gambella and Benishangul Gumuz have been created is for the purpose of ensuring the political dominance of the indigenous groups". ${ }^{136}$ This is clear from the intention of the constitutional drafters in which they recognized only nine states despite the existence of more than eighty ethnic groups. If legitimate mechanisms of empowering these groups are not realized, then they will end up becoming subordinates and the whole purpose of national self-determination will not be served.

\footnotetext{
${ }^{132}$ See, Proclamation 532/2007, Article 45(1)(b).

${ }^{133}$ Ibid, Article 45(1) (b).

${ }^{134}$ Assefa Fiseha, Constitutional Adjudication, supra note 125, p. 28.

${ }^{135}$ Id, 25.

${ }^{136}$ Speech made by Dr. Gebreab, former Minister of State at the Ministry of Federal Affairs at the $1^{\text {st }}$ National Conference on Federalism, Conflict and Peace Building, Addis Ababa, May 5-7, 2003 quoted in Assefa, Constitutional Adjudication, supra note 125 , p. 26.
} 


\section{b) Against the language requirement}

Those who strongly oppose the decision argue that "it is a reversal of past injustice which meets fire with fire as it tries to correct past discrimination with present discrimination rather than uproot discrimination in all of its forms". ${ }^{137}$ According to this view, the language requirement "is a move from one extreme to the other". 138

Under the new electoral law, being versed with the working language of the region or the language of the place of intended candidature is put as an alternative requirement implying that a candidate for instance, in Benishangul Gumuz who is well versed with the Berta language, can run for political office without the need to know the working language of the region which is Amharic. ${ }^{139}$ This will then be missing the whole purpose of the Proclamation. The reason behind the decision of the HoF was that if a member within a state council is not able to communicate fluently with the other members, then it will be very difficult for the council to conduct its normal transactions. ${ }^{140}$ But according to the Proclamation, since the working language and local vernacular are put as an alternative, a candidate who is well versed in the local vernacular can enter into the state council in Benishangul even if he does not know the working language of the region, which is Amharic.

The issue of regional minorities is another point at stake. Given the fact that none of the nine regional states are ethnically homogenous and minorities are already underprivileged in these regions, the addition of the language barrier will eventually lead to under-representation or no representation at all in their respective state councils.

The other strong argument against the language requirement is that "it is one which opens a door for subjective discrimination". ${ }^{141}$ Since, the question of

${ }^{137}$ Takele Soboka, "The Interplay of Equality Clause and Affirmative Action Measures under the Ethiopian Constitution: The Benishangul Gumuz Case and Beyond", in Girmachew Alemu and Sisay Alemahu (eds.) 2008, The Constitutional Protection of Human Rights in Ethiopia: Challenges and Prospects, Ethiopian Human Rights Law Series, Vol. 2 (Dec. 2008), p. 94.

${ }^{138}$ Ibid.

${ }^{139}$ It is interesting to notice here that if a person joins the regional council without knowing its working language, what is the need for knowing the language of the region? Acquaintance with the working language was one of the grounds which the House of Federation considered in validating the language requirement of the Proclamation and in declaring the decision of the NEBE unconstitutional.

${ }^{140}$ Decision of the HoF, supra note 129.

${ }^{141} C f$, Advisory opinion given by Ato Kifle Wodajo to the House of Federation on the constitutionality of Article 38 (1) (b) of Proclamation 111/1995 on file with the author. 
fluency in any language and the ability to use that language for different purposes requires factual determination in each case, there is a problem as to who is to make that determination and on what basis or criterion. Are all candidates running for an elective office in an electoral district to be subjected to a similar test? If so, who will be mandated to carry out the task of evaluating a candidate's proficiency? Is such a determination to be conducted by the ethnic identification of the would-be candidate or is there any other objective standard for ascertaining the allegation/s that may arise against a would-be candidate? Does being versed, with the working language or the local vernacular include one's ability to write only or to speak the language as well? What about cases of mutually intelligible languages where people are able to communicate with each other, without one not being well versed with the language of the other? ${ }^{142}$

Looking specifically at the case of Benishangul can illustrate the implications of the decision and the Electoral Law on the regional minorities found in the regional states. As mentioned earlier, the working language of the Benishangul Region (the language in which the activities of the regional state council are to be conducted) is Amharic. According to Article 45(1)(b) of Proclamation $532 / 2007$, a person will be eligible for candidature where he is versed either in the working language of the regional state or alternatively the language of his/her area of intended candidature.

In the case of the first requirement, since the working language of the regional state is Amharic, any person who is versed with the Amharic language can run for political office. But, the alternative condition is ambiguous. What does the area of intended candidature mean? Does it refer to the language of the region or the language of the specific electoral district in which one is running for political office? If we are to take the first modality as a way in which the wording "area of intended candidature" is to be interpreted, then regional minorities will not be the beneficiaries of the outcome. This is because regional minorities in most scenarios have a language different from the working language of the region except for regional states which have adopted Amharic as their working language.

If we are to take the second modality as the mechanism of interpretation then one has to know for sure what the language of the specific electoral district is. This may be construed form the fact that if there is the applicability of the "administration of nationalities" then the "area of intended candidature" could be the language adopted by the specific area of administration. However, such arrangements only exist in Amhara and SNNPR regional states.

Generally speaking, one can infer form the preceding arguments that the regional minorities in Benishangul (except the Amhara) which are not capable of speaking the Amharic language will not be eligible for electoral candidature.

${ }^{142}$ Advisory opinion given by Ato Kifle Wodajo, Ibid. 
Submitting the issue again for constitutional interpretation will be a futile undertaking because, a decision given by the House has the effect of being a binding precedent for similar cases. ${ }^{143}$ Hence, at this point, the quest of these non-indigenous minorities for share of political power and adequate representation is something that will continue unless other mechanisms of political inclusion are put in place.

\section{The Implications of the Electoral System for Elections at the Federal and Regional Levels}

As has been described in the previous chapter, the four ethnic groups of Ethiopia (Amhara, Oromo, Tigray and Somali) together form an overwhelming majority. In addition to the existence of these four populous ethnic groups, the country is also inhabited by numerous and diverse ethnic groups. Hence, there is the need to adopt an electoral system which best suites this multiethnic character of the nation. "Since 1991, elections in Ethiopia are based on a plurality system of votes, with single-seat constituencies drawn on the basis of Woreda administrative units". ${ }^{14}$

The Constitution has also adopted the same modality with respect to the House of Peoples Representatives. The House is composed of representatives of the country. Accordingly, elections to the House are conducted by means of general and direct elections under the first past the post electoral system. ${ }^{145}$ At the federal level, this implies that only an ethnic group which constitutes a majority in a region will be entitled to send its representatives, despite the presence of numerous minorities. For example, in the Amhara regional state the only representation will come from the Amhara ethnic group despite the existence of numerous regional minorities within it, because, the Amhara is the numerical majority within the region, unless consideration of minorities is made in setting up electoral constituencies.

This will also be the case in the multiethnic region of Benishangul and Gambella where the non-indigenous groups are relatively smaller in number than that of the indigenous ones. Hence, under the plurality (first past the post) system where absolute majority is not necessary, single vote supremacy can

\footnotetext{
${ }^{143}$ See, Proclamation No 251/2001, Consolidation of the House of Federation and the Definition of its Powers and responsibilities Proclamation, Federal Negarit Gazeta, $7^{\text {th }}$ Year, No. 41, Addis Ababa, $6^{\text {th }}$ July 2001, Article 11.

${ }^{144}$ Tafesse Olika and Aklilu Abraham, "Legislation, Institutions and the Post 1991 Elections in Ethiopia" in Kassahun Berhanu et.al.(eds.), 2007, Electoral Politics, Decentralized Governance and Constitutionalism in Ethiopia (Addis Ababa University Press), p. 99.

${ }^{145}$ Article 54(2) of the FDRE Constitution.
} 
determine the winner. Hence, not all ethnic groups will have their representation in the House of Peoples Representatives from their own place of residence. If that minority ethnic group has a state outside its place of residence, it might get a representation via that line although this cannot be called representation proper. Otherwise, ethnic groups which do not have a mother state and that cannot constitute a majority in an electoral district will be outside the ambit of representation in the House. ${ }^{146}$

The problem arises not only because of the modality of the electoral system adopted. It is also due to the small bargaining power of the states in the formulation of the electoral laws of the country. The power to enact laws concerning political parties and elections so as to give practical effect to the political rights provided in the Constitution is the duty of the federal government. ${ }^{147}$ This is done through the House of Peoples Representatives. This means, regional states are not entitled to formulate their own electoral system taking into consideration their population size, ethnic diversity and the long established communal relationships of their inhabitants. They only function within the emblem of an electoral law of the federal government. Since some regional states have a more diversified population than others, adopting a country-wide electoral system without a mechanism by which these states are to deal with their diversified population seriously affects the representation of minorities in the regional states.

Let us now see the implications of the electoral law in a diversified population. Proclamation No. 532/2007 clearly states that "[a] candidate who received more votes than other candidates within a constituency shall be declared the winner". ${ }^{148}$ Most commentators agree that the plurality (first past the post) system is contrary to the principles of "pluralist multi-party democracy". ${ }^{4}{ }^{1}$

The winner takes all principle presents a significant problem in pluralistic societies, particularly where ethnic and cultural divisions have led to the formation of ethnic political parties and the division of the population along ethnic lines. ${ }^{150}$ In a multiethnic society, opting for the plurality system favours the majority by way of determining election results on the basis of a relative majority and reduces the chance of smaller and minority groups to be elected. The system exaggerates the representation of the winning party but fails to

\footnotetext{
${ }^{146}$ However, it is worth noting here that they might secure a seat in the House of Peoples Representatives through minority nationality representation guaranteed under the constitution.

147 Article 51(15) of the FDRE Constitution.

148 Proclamation No 532/2007, Article 25.

149 Tafesse and Aklilu, supra note 144, p. 100.

${ }^{150} \mathrm{Id}, 101$.
} 
reflect the various opinions of the voters in the elected assemblies. In other words, election results are decided on the basis of very few votes achieved relative to the total votes cast. ${ }^{151}$ This is particularly problematic for minority groups, which cannot constitute a majority in each and every electoral district.

In the first past the post electoral system, even a minimal majority is enough to gain a contested seat. In effect, proportional representation where smaller parties can get a voice without necessarily getting the highest number of votes in any of the electoral constituencies is avoided. ${ }^{152}$ In this respect, most commentators argue that the first past the post electoral system is not the ideal type for Ethiopia where national consensus is lacking among the competing parties and ethno-nationalist elites of the country. ${ }^{153}$ This also extends to elections conducted to the regional state councils, where the regions are composed of multiple ethnic groups.

\section{Fortification by a Fitting Electoral System}

The electoral system of Ethiopia, as has been shown above, has presented the different ethno-linguistic groups of the country with a lot of problems, especially in light of their ambition to an equitable and adequate share of political power in the respective federal and regional councils. Generally speaking, the British style first past the post electoral system is not the best approach to address the political rights of the different ethnic groups in multiethnic societies like Ethiopia. This will also apply to the multiethnic regional states within the federation. Even though, none of the Ethiopian federated states can be described as homogenous, some of them are more diverse in their ethnic compositions than the others. Especially, the Benishangul Gumuz, SNNPR and Gambella regional states are multiethnic regions within a multiethnic country.

Moreover, the electoral constituencies have not been subject to change as per the new electoral law of the country. The functioning constituencies are thus the ones that are already set up by taking into consideration the 100,000 population. The new electoral law, which stipulates that electoral constituencies shall be established taking into consideration population size of the country has not been implemented. Despite the variation that has appeared within the formerly setup electoral constituencies, this has simply been neglected.

The new electoral constituencies should be established based on the new electoral law of the country, and this should take into consideration the

\footnotetext{
151 Ibid.

${ }^{152}$ Merera Gudina (2003), Ethiopia: Competing Ethnic Nationalism and the Quest for Democracy 1960-2000 (Shaker publishing), p.133.

153 Ibid.
} 
significant numerical presence of regional minorities (i.e. they should not always be made minorities in each electoral district). This needs some sort of gerrymandering which warrants redrawing the map of the electoral districts to serve the purpose of all ethnic groups in the regional states. This implies that electoral districts should be drawn up, especially in areas where the regional minorities are found territorially concentrated so that constituencies could be established in a manner that they will constitute numerical majorities in constituencies. This will particularly address the needs of regional minorities even within the first past the post electoral system since they can constitute a numerical majority on a particular district.

Taking into consideration the country's long history of competing ethnic nationalisms and lack of consensus, the best option is to adopt the proportional representation system at the federal as well as at regional level of government structure. This is because, in the proportional system of representation, a contested seat will not simply be won by a simple majority vote, but rather, it will be distributed among candidates, proportionately; in accordance with the percentage of votes they have secured.

This can be achieved by one of the following two mechanisms. The first one is amending the stipulation of the FDRE Constitution which embodies the first past the post electoral system and putting in place the proportional representation system. But this may be a very remote ambition, because, since the adoption of the FDRE Constitution, not a single provision has been amended or struck out.

The other option is amendment of the electoral law of the country, especially, the section which deals with the electoral system. This could be done without the total rejection of the plurality system. The former system can be used to elections conducted at the federal level, i.e. to the HoPR, while in the case of the latter, states would be allowed to devise their own electoral systems in accordance with their own specific needs. In regional states where there exists a huge presence of ethnic diversity, it could be stipulated that for the purpose of conducting elections to the regional state council, the proportional representation mechanism could be used. This enables the regional minorities to secure a seat in the regional state councils proportionate to their population size without requiring them to constitute a numerical majority in each electoral constituency.

It cannot a priori be said that a certain type of electoral system is preferable to another. Each individual case calls for its own solution. Nevertheless, under a scheme of single electorate like the case in Ethiopia, the choice of an electoral system should be made based on whether the country has a communal or inter communal party system. ${ }^{154}$ Laponce notes the following:

${ }^{154}$ Laponce, supra note 73, p. 338. 
If there is a system in which majority and minority collaborate in the same political parties, majority systems should be favored by the minority in so far as it tends to the creation of a two-party system in which the minority group has a greatly increased bargaining position. However, if there is a communal party system, that is to say, a system in which, because of the minority's own choice or because of the majority's hostility, the parties are built along communal lines, proportional representation is to be preferred. ${ }^{155}$

This, exactly is, the case in Ethiopia. Therefore, the plurality system in general should be replaced by the proportionality system. But in cases where it is not possible to realize such an undertaking, both can be utilized complementarily. This can be achieved by granting states the right to devise their own electoral systems as per their own needs, subject to a general framework that stipulates the ground norms.

\section{Concluding Remarks}

The preceding sections have assessed the interplay of the electoral system in the context of Ethiopia's current ethnic federal structure. Particular assessment is made on the notions of electoral systems and ethnic minorities. The viability of political representation of minorities has been highlighted from the point of an electoral system functioning within an ethnic federal structure. This issue has been evaluated under the premise that, only nine regional states have so far been formed, despite the existence of more than eighty ethnic groups.

The Electoral Law and the setting up of electoral constituencies (especially for the purpose of representation at the regional council level) have played a significant role in hindering different ethnic groups, especially regional minorities, from securing adequate representation proportional to their numerical presence. This is mainly because the 'first past the post' electoral system declares the winner by a simple majority of votes, and in effect reduces the rights of regional minorities, and minorities also constitute a numerical minority in most of the electoral constituencies.

The Electoral Law's stipulation of language as a legitimate criterion for political candidature has also presented the different regional minorities with a huge barrier to compete for political representation. A political candidate who runs for political office has either to know the working language or the local vernacular (the indigenous language) of the region. This will, in effect mean that other regional minorities, who know neither Amharic nor the local vernacular of the region, cannot run for political candidature. This stipulation of the electoral law erodes constitutionally guaranteed political, linguistic and cultural rights.

${ }^{155} \mathrm{Id}, 338-339$. 
With respect to electoral constituencies, they should strictly be demarcated by taking population size as stipulated in the electoral law of the country. Meanwhile, due consideration should be made to the interest of all ethnic groups especially the rights of minorities for equitable representation, and that electoral constituencies are not always drawn contrary to their interests. Taking into consideration the numerical presence of minorities in the region, constituencies should be drawn to allow them to be majorities within some constituencies.

Due attention should also be given to the demand for equitable representation in the electoral system and the setting up of electoral constituencies. The 'first past the post' system, as outlined earlier excludes minorities from political representation and may at times understate combined majority votes. Therefore, the proportional representation system should be adopted either replacing the already existing system or in combination with it. To this end, regional states should be allowed to devise and adopt the electoral system suitable to them taking into consideration the diversity and need of their population. However, pursuits of embracing the proportional system require deeper study on the particularities of every ethnic group and the need of the country in general, and in effect, such pursuits call for series of national dialogues. 